\title{
腋窩部㓔痕拘縮の治療経験
}

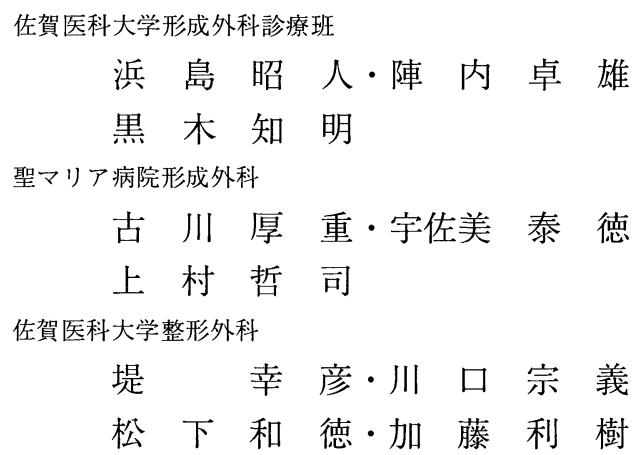

\section{Treatment for Scar Contracture of the Axillary Resion}

by

\author{
Akito Hamajima, Takao Jinnai and Tomoaki Kuroki \\ Department of Surgery (Plastic \& Reconstructive Surgery), \\ Saga Medical School \\ Atushige Yoshikawa, Yasutoku Usami and Tetushi Uemura \\ Division of Plastic \& Reconstructive Surgery, \\ St. Maria Hospital, Kurume \\ Yukihiko Tutumi, Muneyosi Kawaguchi, Kazunori Matushita \\ and Toshiki Katou \\ Department of Orthopedic Surgery, Saga Medical School
}

From 1982 to 1991, we have treated 26 cases of axillary scar contracture, caused by burns, including 1 cases of electrical burn.

We classified the axillary contractures into two types.

I. A wed formation on the anterior and/or posterior axillary line.

II. A scar contracture of the entire axillary region.

For type I. we used local flaps, especially the 5-flap technique.

For type II. free skin grafts were our first choice. But when the axilly region was deeply injured, as in electrical burns, flaps (myocutaneous or fascio-cutaneous) were needed for the reconstruction.

\section{は じめに}

腋窩部の瘀痕拘縮はおもに熱傷によっておこること が多く，瘷痕の位置によって拘縮も様々である。この ため, 腋窩部疲痕拘縮の外科的療法として, 遊離植皮 術 7)91, 有茎植皮術（局所皮弁 4) 7) 9), 筋皮弁, 筋弁, 筋膜皮弁 1) 2) 4)，遊離組織移植 ${ }^{8)}$ などの方法が報告
されている.

今回，われわれは，腋窩部痴痕拘縮の術式およびそ の適応につき検討し，若干の文献的考察を加えたので 報告する.

\section{症 例 と分 類}

1982 年から 1991 年までの 10 年間に 22 例 26 部位 
を経験した. 原因は，1例が電撃傷によるものであり， 他は熱傷であった。

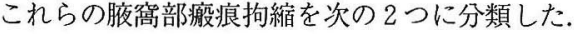

I．腋窩の前縁・後縁の痏痕拘縮で水かき状を呈す るもの

II．腋窩部全域にわたる㾮痕拘縮

結果

表 1 に術式とその例数および前記分類との関係を示 す．水かき状を呈する症例には局所皮弁，また，腋窝 全域にわたるものでは遊離植皮術，広背筋皮弁を施行 した.

代表的症例を示す。

症例 1 (図 1)

5 才，女子．熱湯にて受傷．右腋窩部前縁に水かき 形成を認めた。 5-FLAPによる形成術を施行した。

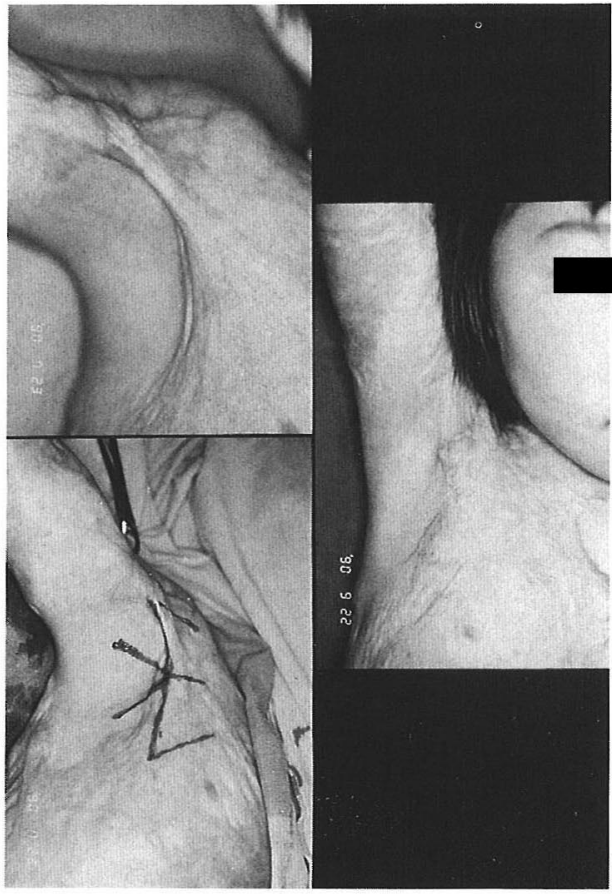

図 1 左上）術前：左下）手術時，5-FLAPにより形 成術を施行した：右）術後 2 ヶ月
表 1 術式と例数 (1982-1991)

\begin{tabular}{|c|c|c|c|}
\hline & & $\begin{array}{r}\text { I. 水かき状を } \\
\text { 呈するもの }\end{array}$ & $\begin{array}{c}\text { II. 腋窩部全域に } \\
\text { わたるもの }\end{array}$ \\
\hline \multicolumn{2}{|r|}{ 遊離植皮術 } & - & 7 \\
\hline 局 & Z 形成術 & 7 & - \\
\hline 所 & 4-FLAP & 1 & - \\
\hline 皮 & 5-FLAP & 7 & - \\
\hline \multirow[t]{3}{*}{ 弁 } & $Z+5-F L A P$ & 3 & - \\
\hline & 広背筋皮弁 & - & 1 \\
\hline & 計 & 18 & 8 \\
\hline
\end{tabular}

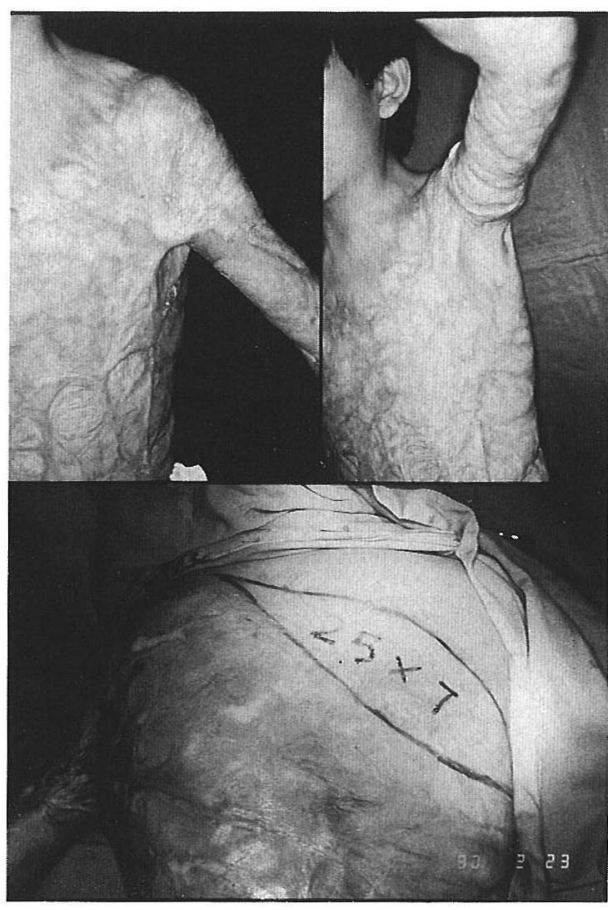

図 2 左上) 術前：下) 手術時, 左腋窩部の切開線と 背部の採皮部を示す：右上) 術後 1.5 年

\section{症例 2（図 2)}

11才，男子．熱湯にて受傷. 左腋窩部全域に㓔痕拘 縮を認めた，背部からの全層植皮を施行した，術後 1.5 年の現在左肩の拘縮は外転, 屈曲 $30^{\circ}$ から $120^{\circ}$ に 改善されている。 


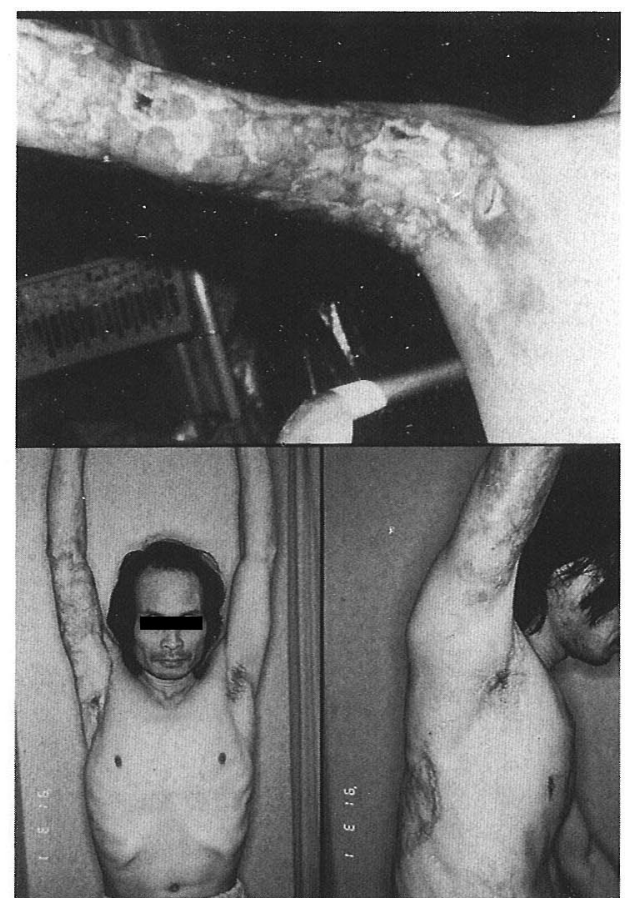

図 3 上）術前：左右下）広背筋皮弁による右腋蒚部 再建術後 3 年

\section{症例 3 (図 3)}

35才，男性. $66000 \mathrm{~V}$ の高圧電流による電撃傷．遊 離植皮による創閉鎖を施行するも右上腕二頭筋の一部 が壊死におちいり，内転拘縮をきたしたため，広背筋 皮弁による再建を行った。 2 回の徐脂術をおこない ROM は正常範囲で ADL に問題ない.

\section{考察}

腋窩部㓔痕拘縮の形成術では，遊離植皮術，有茎植 皮術が用いられることが一般的である. 特に, 水かき 状を呈する分類 I の症例では，局所皮弁による形成術 が行われることが多い3）9．これには，Z形成術， 5 -FLAP， 4 -FLAP やこれらの組合せが主として用 いられる。これらの術式のシェーマを図 4 に示す，症 痕部に皮弁を作成する場合，健常皮膚の場合と比べ皮 弁の入れ換えが困難なことがあり，そのため皮膚欠損 が生じ，遊離植皮を必要とすることもある．また，健 常皮膚で行う場合よりも皮弁の入れ換えによる延長効 果も少ない. 図 4 に示した局所皮弁の中で 5 -FLAP は, $2 つ の Z$ 形成術と V-Y Advancement Flap を組み
合わせた形であり，延長効果も大きく，腋毛部の位置 もあまりかわらず，水かき状を呈する痏痕拘縮では有 用と思われる.この他, 文献的には正方弁法 ${ }^{4)}$, Propeller Flap ${ }^{5)}$ などの報告がみられる.
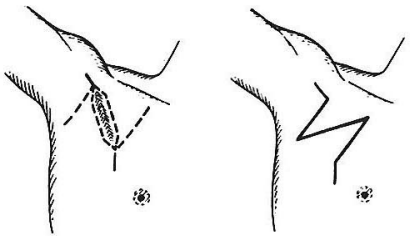

Z 形成晚
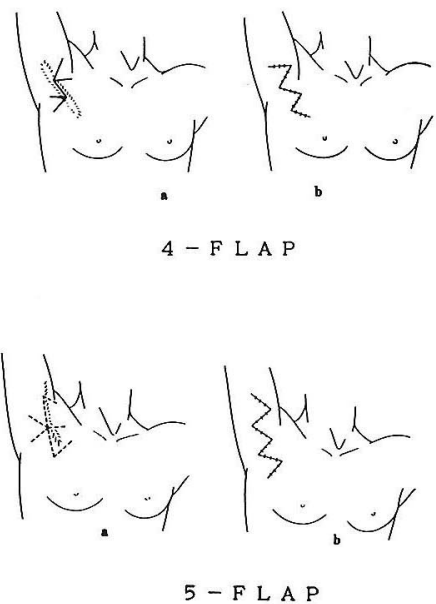

図 4 腋窩部で用いられる局所皮弁

腋窩部全域にわたる㓔痕拘縮では，拘縮を十分に解 除し，遊離植皮術が行われることが多い7)9). われ われも first choice として遊離植皮術を行っている. しかし，腋窩部の深部まで損傷が及んでいるものでは 遊離植皮術は不適当であり，皮弁による再建が必要と なる ${ }^{91}$ ，われわれも電撃傷の症例に対し，広背筋皮 弁を施行した。しかし，筋弁・筋皮弁では筋機能噩失 による機能障害を考慮しなければならない．広背筋皮 弁においては，日常生活上問題となるような障害はみ られず，大きな皮弁作成が可能であり，腋窩部の再建 には有用と考えられる。しかし，近年の筋膜皮弁の開 発により, Scapular Flap ${ }^{2)}$, Parascapular Flap, Cervicodorsal Flap, Cervicoscapular Flap ${ }^{4) 6) な と ゙ て ゙ ~}$ の再建も報告されている。これらの筋膜皮弁は，遊離 植皮術と比べ術後固定が容易である．採皮部の㓔痕を 
考えると背部からの皮弁移植は整容的に優れている， 筋肉は使用しないため筋機能喪失がない ${ }^{4)}$, などが 利点として述べられている。 これらの筋膜皮弁を腋窩 全域の㓔痕拘縮形成術の first choice としている報告 もある ${ }^{4)}$ が，われわれは遊離植皮術を first choice と 考えている.これは遊離植皮術を行なった自験例 7 例 で，拘縮も十分解除されていることによる. しかし， 損傷が深部に及んだ場合や，再拘縮をきたした症例で は筋膜皮弁は有用と考える. 今後, 症例によっては使 用してみたいと考えている。

\section{ま と め}

腋窩部痦痕拘縮の外科的療法につき，自験例をもと に術式とその適応につき検討を加えた。

腋窩部前・後縁に水かき状を呈するものでは局所皮 弁（とくに5-FLAP）が，腋窩全域にわたる躿痕拘 縮では遊離植皮術が適応となる．深部まで及んだ夜窩 全域の㓔痕拘縮では, 筋皮弁, 筋膜皮弁などによる再 建が必要と考えられた.

\section{女 献}

1) Achauer, B. M., Spenler, C.W., and Gold, M.E. : Re- constructure of axillary burn contractures with the latissimus dorsi fascicoutaneous flap. J.Trauma, $28: 211$ $-213,1988$.

2) Diamond, M., and Barwick, W. : Treatment of axillary burn scar contracture using an arterialized scapu. lar island flap. Plast. Reconstr. Surg., 72:388-390,1983.

3) Hanumadass, M., Kagan, R., Matsuda, T., and Jayaram, B. : Classification and surgical correction of postburn axillary contractures. J. Trauma, 26:236-240 ,1986.

4）百束比古, 文入正敏 : 腋窝部熱傷後㓔痕拘縮の形成 手術について。熱傷, 15:35-42,1989.

5) Hyakusoku, H., Yamamoto, T., and Fumiiri, M. : The propeller flap method. Br. J. Plast. Surg., 44:53-54, 1991.

6) Hyakusoku, H., Yoshida, H., Okubo, M., Hirai, T., and Fumiiri, M. : Superficial cervical artery skin flaps. Plast. Reconstr. Surg., 86:33-38,1990.

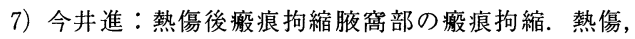
12:92-93,1986.

8）大森喜太郎, 高田裕子, 阪田和明 : 微小血管外科を利 用した遊離筋皮弁および筋弁移植. 筋皮弁と筋弁, 153-183.丸毛英二編，克誠堂，1985.

9）鬼塚卓弥：形成外科手術書 (第 2 版)，950-953. 南山堂, 1982. 